\title{
Improving Students' Sustainability Awareness through Argument-driven Inquiry
}

\section{Erning Rahmadini Salsabila1*, Agus Fany Chandra Wijaya², Nanang Winarno³}

\author{
${ }^{1}$ Al-Azhar Syifa Budi Parahyangan, Bandung, Indonesia \\ ${ }^{2}$ Department of Physics Education, Faculty of Mathematics and Science Education, Universitas Pendidikan Indonesia, Indonesia \\ ${ }^{3}$ International Program on Science Education, Faculty of Mathematics and Science Education, Universitas Pendidikan Indonesia, \\ Indonesia \\ *Corresponding Author. erningrahmadini@gmail.com
}

\begin{abstract}
Sustainability awareness is one of the things that the student should have to help in a caring environment. Sustainability awareness of the student can be built by knowledge and awareness of what should be done or not. The student will be more aware of the students involved and explore more in building a concept about the environmental issue itself. The aim of this study is to investigate the impact of Argument-Driven Inquiry toward students' sustainability awareness in learning global warming. The method used in this research was experimental research. This study used two different groups of student. The first group learned using Argument-Driven Inquiry and the second group learned using Inquiry-based Learning. The population was seventh-grade students in one of Junior Secondary School in Bandung, Indonesia. The purposive sampling technique was used to choose the sample. The participants consist of 52 students from both groups. Each group consists of 26 students. The data were collected by giving the questionnaire of sustainability awareness. The questionnaire consists of 15 items. The result of this study shows the different percentage in the level of students' sustainability awareness between the two groups. The most different percentage is on the sustainability practice awareness aspect. The group that used Argument-Driven Inquiry has percentage $40.7 \%$ which means as medium and the group that used Inquiry-based Learning has percentage 37.6\% which means as low. Based on the result, Argument-Driven Inquiry gives a better impact on students' sustainability awareness. Argument-Driven Inquiry can be considered as one of the alternative teaching models that can give a better understanding in building the awareness of Junior Secondary School student.
\end{abstract}

Keywords Sustainability awareness, Argument-driven inquiry, Global warming

\section{INTRODUCTION}

Argument-Driven Inquiry is the learning model that conducts argumentation session in the part of the learning process. Argument-Driven Inquiry has the purpose to give more place of argumentation in the inquiry process in order to improve the learning outcome (Hasnunidah, Susilo, Irawati \& Sutomo, 2015). Argument-Driven Inquiry has seven steps of learning which are the argumentation session is included. Argumentation is one of the ways to facilitate the students in gaining the concept and gaining more reason behind the process of phenomenon happens in nature. The inquiry is often used in the learning activity and argumentation is one of the important things that support the inquiry in the learning process (Aulia, Poedjiastoeti, \& Agustini, 2018). According to Demircioglu \& Ucar (2015) stated that argumentation is not really often to be implemented in learning science.
The implementation of argumentation in learning global warming is one of the important things to support and help a student in explaining the phenomenon. By argumentation, the student can explore more the idea about how and why global warming happens. Global warming is a topic that discusses the environmental issue that happens in nature. The participation of students in environmental issue has been basically built at the school. Besides the theoretical knowledge, the awareness of the environmental issue is also one thing that should the students have (Hamid, Ijab, Sulaiman, Md. Anwar \& Norman, 2017). Students are most likely to do things for a personal material prize or awards because the most student is not doing something where they do not get any direct

Received: 19 September 2018

Revised: 9 January 2019

Published: 11 January 2019 
Table 1 Data of population and sample

\begin{tabular}{llllll}
\hline Group & Population & Sample & $\mathbf{N}$ & $\begin{array}{l}\text { Percen- } \\
\text { tage } \mathbf{( \% )}\end{array}$ & $\begin{array}{l}\text { Total } \\
(\mathbf{\%})\end{array}$ \\
\hline First & $7^{\text {th }}$ grade & Male & 14 & 53.80 & 100 \\
\multirow{2}{*}{ Second } & \multirow{2}{*}{$7^{\text {th }}$ grade } & Female & 12 & 46.20 & \\
& & Male & 13 & 50.00 & 100 \\
\hline
\end{tabular}

impact or advantage for them. According to Sammalisto, Sundström, von Haartman, Holm, \& Yao (2016) stated that students tend to not doing something if there is no advantage for themselves. Sustainability awareness is one of the prerequisites for environmental attitude and behavioral change in caring the natural environment to impede climate change and global warming (Hamid, Ijab, Sulaiman, Md. Anwar \& Norman, 2017). The students probably have a lack of awareness because they do not really understand what is happening in the environment or how global warming damages the environment. This can be a challenge for educators to build or improve the sustainability awareness of students. According to Hodson (2009) stated that the students should be able to have a reason in science, so they can relate the concept and daily phenomenon.

In recent years, many studies have been carried out the implementation of Argument-Driven Inquiry in learning science. Demircioglu and Ucar (2015) have investigated students' argumentation level and science process skill by using Argument-Driven Inquiry (ADI) in learning physic. The previous research from Cetin \& Eymur (2017) has investigated students' writing skill and scientific presentation skill by using Argument-Driven Inquiry (ADI) in learning chemistry. Another research from Walker, Sampson, Southerland, \& Enderle (2016) has investigated students' academic achievement by using ArgumentDriven Inquiry (ADI) in learning chemistry. However, the research that investigates students' sustainability awareness by using Argument-Driven Inquiry (ADI) has not been researched yet. Therefore, this study engaged the concept of climate change, greenhouse effect, and the impact of global warming that utilizes argumentation during the learning process to build the awareness of students about the environment. The aim of this study is to investigate the impact of Argument-Driven Inquiry on students' sustainability awareness in learning global warming.

\section{METHOD}

\subsection{Research Method}

This study used the quasi-experiment method. Quasiexperiment is where the treatment is administered to only one of two groups whose members were randomly assigned (Creswell, 2012). This study was conducted in two different groups of student. The first group learns using Argument-Driven Inquiry and the second group learns using Inquiry-based Learning.
Table 2 Questionnaire sustainability awareness

\begin{tabular}{|c|c|c|c|}
\hline \multirow{2}{*}{ No } & \multirow{2}{*}{ Statement } & \multicolumn{2}{|c|}{ Response } \\
\hline & & Yes & No \\
\hline 1 & $\begin{array}{l}\text { I read about environmental issues in the } \\
\text { mass media }\end{array}$ & & \\
\hline 2 & $\begin{array}{l}\text { I concern about environmental problems } \\
\text { at my place }\end{array}$ & & \\
\hline 3 & $\begin{array}{l}\text { I always discuss environmental problems } \\
\text { with my friends }\end{array}$ & & \\
\hline 4 & I feel disappointed with air pollution & & \\
\hline 5 & I feel disappointed with river pollution & & \\
\hline 6 & I appreciate biodiversity & & \\
\hline 7 & $\begin{array}{l}\text { I concern about smoke that is emitted by } \\
\text { vehicles }\end{array}$ & & \\
\hline 8 & $\begin{array}{l}\text { I try to reduce the amount of waste at } \\
\text { home by collecting materials that can be } \\
\text { recycled }\end{array}$ & & \\
\hline 9 & $\begin{array}{l}\text { I composting the food residue to become } \\
\text { fertilizer }\end{array}$ & & \\
\hline 10 & I do not use a plastic bag to wrap things & & \\
\hline 11 & $\begin{array}{l}\text { I conserve the use of electric energy at } \\
\text { home }\end{array}$ & & \\
\hline 12 & I conserve the use of water supply & & \\
\hline 13 & $\begin{array}{l}\text { I deliver information on the environment } \\
\text { to my family members }\end{array}$ & & \\
\hline 14 & $\begin{array}{l}\text { I involve in the environmental awareness } \\
\text { activities in school }\end{array}$ & & \\
\hline 15 & $\begin{array}{l}\text { I aware of my responsibility towards the } \\
\text { environment }\end{array}$ & & \\
\hline
\end{tabular}

\subsection{Population and Sample}

The location of this study was in one of Junior Secondary School in Bandung, Indonesia. The school used curriculum 2013. The population of this study was seventhgrade students with aged ranged between 13-14 years old. The sample consists of 52 students: 26 (12 female, 14 male) in the first group and the 26 (13 female, 13 male) in the second group. The sample was chosen by purposive sampling technique. Fraenkel, Wallen, \& Hyun (2012) stated that purposive sampling is defined where the researcher uses the judgment to select a sample that they believe, based on prior information, will provide the data they need. The data of the sample can be seen in Table 1 .

\subsection{Research Instrument}

The data was gathered by giving the questionnaire of sustainability awareness to the students. The questionnaire is adopted from Hassan, Noordin, \& Sulaiman (2010) that consist of three aspects of sustainability awareness which

Table 3 Sustainability awareness interpretation

\begin{tabular}{ll}
\hline $\begin{array}{l}\text { Sustainability } \\
\text { Awareness Value }\end{array}$ & $\begin{array}{l}\text { Criteria of Percentage } \\
\text { Response }\end{array}$ \\
\hline $0.0-39.9$ & $\begin{array}{l}\text { Practices that seldom or dislike } \\
\text { being done/low }\end{array}$ \\
Practices that are done/ \\
happened moderate/medium \\
Practices/feelings that are most \\
likely one/happened/high
\end{tabular}


Table 4 Sustainability awareness in the first group

\begin{tabular}{|c|c|c|c|}
\hline \multirow{2}{*}{$\begin{array}{l}\text { Aspect : Sustainability } \\
\text { Practice Awareness }\end{array}$} & \multicolumn{2}{|c|}{ Statement } & \multirow{2}{*}{$\begin{array}{l}\text { Number } \\
\text { of Data }\end{array}$} \\
\hline & Yes & No & \\
\hline Item 3 & 12 & 14 & \\
\hline Item 9 & 5 & 21 & \\
\hline Item 10 & 9 & 17 & \\
\hline Item 13 & 14 & 12 & \\
\hline Item 14 & 13 & 13 & \\
\hline Total & 53 & 77 & 130 \\
\hline Percentage Response & \multicolumn{2}{|c|}{40,76923} & \\
\hline \multirow{2}{*}{$\begin{array}{l}\text { Aspect : Behavioral and } \\
\text { Attitude Awareness }\end{array}$} & \multicolumn{2}{|c|}{ Statement } & \multirow{2}{*}{$\begin{array}{l}\text { Number } \\
\text { of Data }\end{array}$} \\
\hline & Yes & No & \\
\hline Item 1 & 18 & 8 & \\
\hline Item 6 & 22 & 4 & \\
\hline Item 7 & 24 & 2 & \\
\hline Item 8 & 12 & 14 & \\
\hline Item 11 & 22 & 4 & \\
\hline Item 12 & 22 & 4 & \\
\hline Total & 120 & 36 & 156 \\
\hline Percentage Response & \multicolumn{2}{|c|}{76,92308} & \\
\hline \multirow{2}{*}{ Aspect : Emotional Awareness } & \multicolumn{2}{|c|}{ Statement } & Number \\
\hline & Yes & No & of data \\
\hline Item 2 & 22 & 4 & \\
\hline Item 4 & 25 & 1 & \\
\hline Item 5 & 26 & 0 & \\
\hline Item 15 & 24 & 2 & \\
\hline Total & 97 & 7 & 104 \\
\hline Percentage Response & \multicolumn{2}{|c|}{93,26923} & \\
\hline
\end{tabular}

are sustainability practice awareness, behavior, and attitude awareness, and emotional awareness. The questionnaire consists of 15 items with "yes" and "no" choices. The questionnaire of sustainability awareness is shown in Table 2. Items 3, 9, 10, 13, 14, represent students' sustainability practice awareness. Items 1, 6, 7, 8, 11, 12 represents students' behavioral and attitude awareness. Items 2, 4, 5, 15 represent students' emotional awareness.

\subsection{Research Procedure}

In this study, Argument-Driven Inquiry was implemented in the first group. There is seven steps of Argument-Driven Inquiry which are identifying the task and guiding question, design a method and generate data, production of tentative argument, argumentation session, write an investigation report, double-blind group peer review, revise and submit a report. Inquiry-Based Learning was implemented in the second group. The step of InquiryBased Learning includes Identification of the problem, questioning, making a hypothesis, collecting data, analyzing data, and making a conclusion. Both groups were given the topic of global warming. The concept of global warming is limited based on Indonesian Curriculum 2013. The research was conducted in four meetings. The first meeting until the third meeting was for the treatment of ArgumentDriven Inquiry and Inquiry-Based Learning, and the fourth meeting was for giving the questionnaire to the students.
Table 5 Sustainability awareness in the second group

\begin{tabular}{|c|c|c|c|}
\hline \multirow{2}{*}{$\begin{array}{l}\text { Aspect : Sustainability Practice } \\
\text { Awareness }\end{array}$} & \multicolumn{2}{|c|}{ Statement } & \multirow{2}{*}{$\begin{array}{l}\text { Number } \\
\text { of Data }\end{array}$} \\
\hline & Yes & No & \\
\hline Item 3 & 11 & 15 & \\
\hline Item 9 & 1 & 25 & \\
\hline Item 10 & 6 & 20 & \\
\hline Item 13 & 15 & 11 & \\
\hline Item 14 & 16 & 10 & \\
\hline Total & 49 & 81 & 130 \\
\hline Percentage Response & \multicolumn{2}{|c|}{37,69231} & \\
\hline \multirow{2}{*}{$\begin{array}{l}\text { Aspect : Behavioral and } \\
\text { Attitude Awareness }\end{array}$} & \multicolumn{2}{|c|}{ Statement } & \multirow{2}{*}{$\begin{array}{l}\text { Number } \\
\text { of Data }\end{array}$} \\
\hline & Yes & No & \\
\hline Item 1 & 16 & 10 & \\
\hline Item 6 & 23 & 3 & \\
\hline Item 7 & 24 & 2 & \\
\hline Item 8 & 9 & 17 & \\
\hline Item 11 & 22 & 4 & \\
\hline Item 12 & 22 & 4 & \\
\hline Total & 116 & 40 & 156 \\
\hline Percentage Response & 74,35 & 397 & \\
\hline \multirow{2}{*}{ Aspect : Emotional Awareness } & \multicolumn{2}{|c|}{ Statement } & \multirow{2}{*}{$\begin{array}{l}\text { Number } \\
\text { of Data }\end{array}$} \\
\hline & Yes & No & \\
\hline Item 2 & 18 & 8 & \\
\hline Item 4 & 24 & 2 & \\
\hline Item 5 & 24 & 2 & \\
\hline Item 15 & 24 & 2 & \\
\hline Total & 90 & 14 & 104 \\
\hline Percentage Response & \multicolumn{2}{|c|}{86,53846} & \\
\hline
\end{tabular}

\section{RESULT AND DISCUSSION}

Students' sustainability awareness data was collected by conducting questionnaire that consists of 15 items with "yes" and "no" answer options. Students' sustainability awareness has three aspects and it is analyzed by calculating the percentage of each aspect. The questionnaire consists

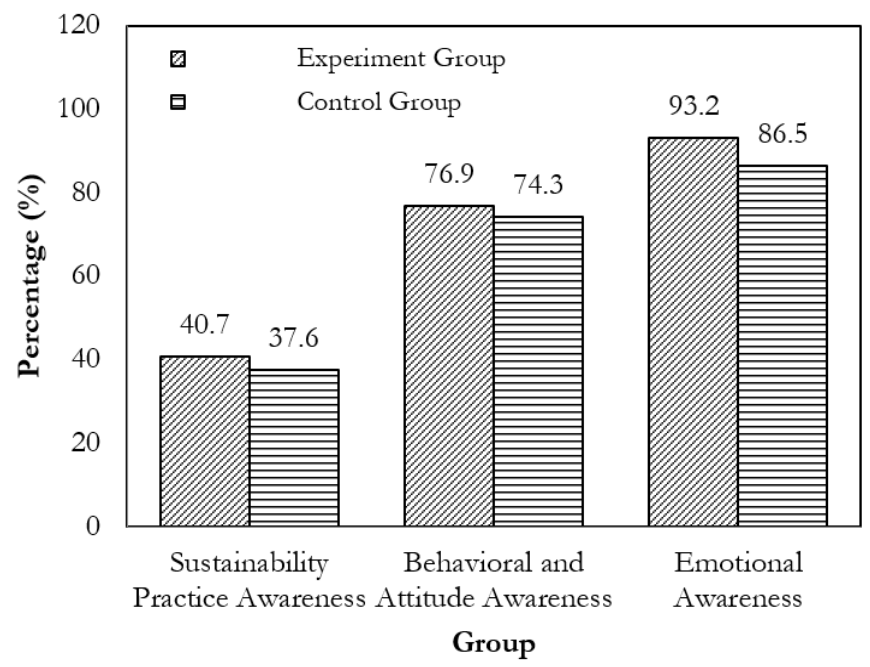

Figure 1 Percentage on each aspect of sustainability awareness 
of items that represent all aspect of sustainability awareness. The level of sustainability awareness is determined based on the percentage score from Hassan, Noordin, \& Sulaiman (2010) that is interpreted in Table 3.

The percentage of students' sustainability awareness was analyzed using Microsoft Excel. Sustainability awareness has three aspects, there are sustainability practice awareness, behavioral and attitude awareness, and emotional awareness. In each aspect, the number of "yes" and "no" answer is calculated and the number of "yes" answer will be divided by the number of all the students' answer both "yes" and "no" on the items of a certain aspect. The analysis of the percentage of sustainability awareness in the first group is shown in Table 4, and the analysis of the percentage of sustainability awareness in the second group is shown in Table 5. The result of students' sustainability awareness in the first and the second group can be seen in Figure 1.

Based on Figure 1, those three aspects of both groups have a different percentage. The percentage of sustainability practice awareness aspect in the first and second group has a different category. In the first group is $40.7 \%$ which categorized as medium, while the second group is $37,6 \%$ which categorized as low. The result means that the first group student has better practice awareness such as discussing or delivering information about

Table 6 Students' activity in the first group

First Meeting
The step of Argumen
Driven Inquiry
Identification of the tas
and guiding question
Designing method and
generate data
Production tentative
argument
Argumentation session
Write an investigation
report
Submit the report

Second Meeting The step of ArgumentDriven Inquiry

Identification of the task and guiding question Designing method and generate data

Production tentative argument

Argumentation session

Write an investigation report

Submit the report

Double-blind peer review

\section{Description of Activities}

The students observe picture and video about climate change.

The students are divided into 5 groups and each group is designing the procedure of experiment about the impact of $\mathrm{CO}_{2}$ toward temperature.

The students analyze the data from the experiment and finding the evidence to support their findings.

Each group delivers argumentation based on the problems that are given on the worksheet. Among groups can perceive, criticize, oppose, and support the statement during this session.

The students are making a report by completing the worksheet.

The students submit the worksheet as their practical report.

\section{Observed Activities}

Most of the students are a very enthusiast in watching video

Some student did not bring tools and materials for the experiment, so other groups have to share and sometimes the number of tools and material is not enough.

The students write the tentative argument on the worksheet

Some students are not conducive, so it disturbs other students who are presenting.

The students are completing the worksheet

The students submit the worksheet

\section{Description of Activities Observed Activities}

The students observe picture and video about the greenhouse effect.

The students are divided into 5 groups and each group is designing the procedure of experiment about the greenhouse effect. The students analyze the data from the experiment and finding the evidence to support their findings.

Each group delivers argument based on the problems that are given on the worksheet. Among groups can perceive, criticize, oppose, and support the statement during this session. The students are making a report by completing the worksheet.

The students submit the worksheet as their practical report.

The student submitted the assignment of making an article and reviewed and given feedback by their classmate

Most of the students are a very enthusiast in watching video

The experiment needs sunlight as the heat energy. There was lack of sunlight so the result of the experiment not really clear.

The students write the tentative argument on the worksheet

Some students are not conducive, so it disturbs other students who are presenting.

The students are completing the worksheet

The students submit the worksheet

The teacher asked the student to make a handwriting article, but some student makes it in the type-writing article. 
environmental problems and doing environmental awareness activity. Based on the number of percentage of behavioral and attitude awareness and emotional awareness aspect in both class have almost the same percentage. In the first group is $76,9 \%$ and the second group is $74,3 \%$. The behavioral and attitude awareness aspect in both groups is categorized as a medium. The result means that both groups of student have the same level of awareness to implement activities such as conserve energy and water, and recycling. The emotional awareness aspect of the first group is $93,2 \%$ and the second group is $86,5 \%$ which is categorized as high. The result means that the students in both classes are very aware of the response to environmental issues that happen.

From the data, it shows that the students from both groups are really aware of the responsibility to the environment. Students were very aware of their responsibility to environmental problems around them. They felt "very disappointed" about air and river pollutions. This is in line with the research from Hassan Hassan, Noordin, \& Sulaiman (2010) that the emotional awareness aspect of the student is high. The students understand and know that there must be a balance between environments.
The behavioral and attitude awareness aspect in both classes is medium. For behavioral and attitude awareness aspect, students are required to implement actions such as reading environmental issues, appreciating, recycling, and conserving energy and water. The result of behavior and attitude awareness in research from Hassan Hassan, Noordin, \& Sulaiman (2010) is also medium. It said that the students may not really have high awareness in reading environmental issues and appreciating environmental condition around them.

The sustainability practice awareness aspect has the lowest percentage among another aspect. This aspect is very difficult to be achieved. This is in line with the study from Hassan, Rahman, \& Abdullah (2011) that students had a good awareness of environmental problems but yet had not changed in practice. The student should have awareness in discussing or delivering information about environmental problems and doing environmental awareness activity. The students might get environmental and awareness lesson from home and school. Knowledge is the thing that affects practice. The different percentage of two groups is caused by the model that was implemented in the class. The activity of the first group in all meetings

Table 7 Students' activity in the second group

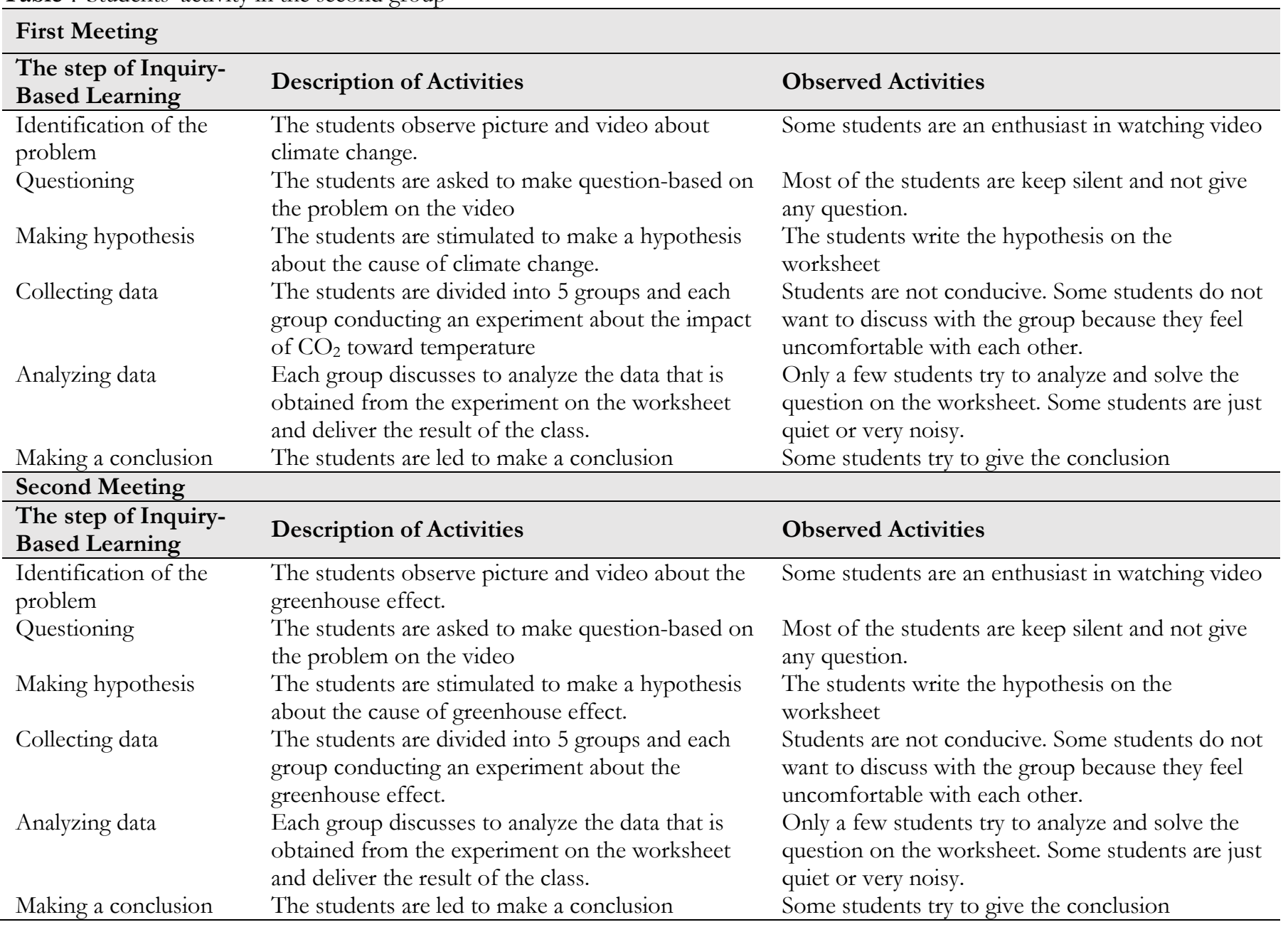


can be described in Table 6. The activity of the second group in all meetings can be described in Table 7.

From the Table 6 and 7, it can be seen that the first group that used Argument-Driven Inquiry, the students are asked to have argument about what and why they have to do, such as arrange the procedure of experiment, filling the solution of the problem on the worksheet and argue it in class, while in the second group is different. The inquiry process itself gives more benefit to students in improving knowledge (Wardani \& Winarno, 2017). The inquiry process that is supported by argumentation gives more space to the student to explore the idea.

In the first group, there is also a step called double blind-peer review. The group of students in each class is asked to make an article that discusses alternative energy, what activity that can be done to maintain our surrounding at home and school, and what simple activity that can be done routinely to reduce the global warming. Then, the article will be reviewed or given any feedback by their classmate without knowing whose article they assessed and who assessed their article, then the article will be given back to the group author to be revised and submitted. While in the second group there is no double-blind peer review. The students are only asked to make the same theme article and then submit it directly to the teacher.

By having those arguments in learning global warming, the students can integrate the environmental condition, social, and economic dimensions of sustainability issues. The students can relate their past, present, and future condition so that the students gain a better understanding. At the same time, by arguing allows students to have a different point of views and opinions to be solved. The students can reflect on what is happening in global warming, what is being learned, and critically make the decision to participate in handling the problem of the topic which is learned in the classroom. This is in line with the result from Pauw, Gericke, Olsson, \& Berglund (2015) that as the teacher integrate the environmental condition on the past, present, and future, the students gain the more knowledge and critically reflect on what is happening and participate in decision making to practice their knowledge. The previous study from Labog (2017) found that the learning process on concept and practice at school can help in strengthening the linkage to the environment to achieve sustainability awareness. The more knowledge will increase the students' practice awareness. This is in line with the statement from Sivamoorthy, Nalini, \& Kumar (2013) that knowledge does not influence emotional and behavior, but influence the students' practice awareness.

This level of sustainability practice awareness needs to be built more in education at school. Besides theoretical knowledge, the school needs to give more practical experience to trigger the intended lifestyle or behavioral change among students, so that the students will have more sustainability practice awareness (Hamid, Ijab, Sulaiman,
Md. Anwar, \& Norman, 2017). The teacher should develop the criteria that still lack in students to develop sustainability awareness. However, Cottrell \& Graefe (1997) stated that behavior in terms of environmental practices was a complex task and influenced by many other factors.

Comparing the activity in both groups, the first group and second group have different activities. Based on table 6, in the first group which used Argument-Driven Inquiry, there is argumentation session in the activity, while in the second group there is no argumentation session. In the first group, the students participated more in a group discussion during the argumentation session. The students have more opportunity to explore the idea. Each group delivered argument based on global warming problems. Among groups perceive, criticize, oppose, and support the statement during this session. Then, the teacher clarified the students' opinion. In argumentation session, students had more opportunity to exchange the ideas in class. In the first group, there was also a double-blind peer review. The students submit the assignment of making an article and the article was reviewed and given feedback by their classmate. These two activities are the most influenced the level of sustainability awareness of students. By increasing more knowledge of students about global warming, the students' will learn more about how to be aware of the environment.

\section{CONCLUSION}

Argumentation in the learning process helps the student to explain how the phenomenon happens. Argumentation in the inquiry process also helps the student to gain more reason behind a process of the phenomenon itself. The students in the experimental group have a higher percentage in all aspects. The difference can be seen clearly in the sustainability practice awareness aspect which is the first group that used Argument-Driven Inquiry has the medium percentage, while the second group has a low percentage. It can be concluded that Argument-Driven Inquiry helps the students in gaining the higher percentage on sustainability awareness in all aspects. Argument-Driven Inquiry can be considered as one of the alternative teaching models that can give a better impact on students' sustainability awareness.

\section{ACKNOWLEDGMENT}

The author acknowledged the principal of the school Mr. Roberto Leonardo, S.Pd who gave permission to the author in conducting this research. The author also acknowledges the science teachers who also have a role as the authors' supervisor Mrs. Wiwin Sriwulan, S.Pd, and Mrs. Rika Siti Jahara, S.Pd who helped the author in finishing the research about Argument-Driven Inquiry in several meetings. 


\section{REFERENCES}

Aulia, E. V., Poedjiastoeti, S., \& Agustini, R. (2018). The Effectiveness of Guided Inquiry-based Learning Material on Students' Science Literacy Skills. Journal of Physics: Conference Series, 947(1), 012049.

Cetin, P. S., \& Eymur, G. (2017). Developing Students' Scientific Writing and Presentation Skills through Argument-Driven Inquiry: An Exploratory Study. Journal of Chemical Education, 94(7), 837-843.

Cottrell, S. P., \& Graefe, A. R. (1997). Testing a conceptual framework of responsible environmental behavior. The Journal of Environmental Education, 29(1), 17-27.

Creswell, J. W. (2012). Educational Research: Planning, Conducting and Evaluating Quantitative and Qualitative Research (Fourth Edi). Lincoln, Nebraska: Pearson.

Demircioglu, T., \& Ucar, S. (2015). Investigating the effect of argumentdriven inquiry in laboratory instruction. Kuram ve Uygulamada Egitim Bilimleri, 15(1), 267-283.

Fraenkel, J. R., Wallen, N. E., \& Hyun, H. H. (2012). How To Design and Evaluate Research in Education (Eight Edit). New York: McGraw-Hill.

Hamid, S., Ijab, M. T., Sulaiman, H., Md. Anwar, R., \& Norman, A. A. (2017). Social media for environmental sustainability awareness in higher education. International Journal of Sustainability in Higher Education, 18(4), 474-491.

Hasnunidah, N., Susilo, H., Irawati, M. H., \& Sutomo, H. (2015). Argument-Driven Inquiry with Scaffolding as the Development Strategies of Argumentation and Critical Thinking Skills of Students in Lampung, Indonesia. American Journal of Educational Research, 3(9), 1185-1192.

Hassan, A., Noordin, T. A., \& Sulaiman, S. (2010). The status on the level of environmental awareness in the concept of sustainable development amongst secondary school students. Procedia - Social and Behavioral Sciences, 2(2), 1276-1280.

Hassan, A., Rahman, N. A., \& Abdullah, S. I. S. S. (2011). The level of environmental knowledge, awareness, attitudes and practices among UKM students. https://doi.org/10.1016/j.foodcont.2013.09.036.

Hodson, D. (2009) Teaching and Learning about Science: Language, Theories, Methods, History, Traditions, and Values. Canada: Sense Publisher.

Labog, R. A. (2017). Teachers' Integration of Environmental Awareness and Sustainable Development Practices. Asia Pacific Journal of Multidisciplinary Research, 5(3), 102-110.

Pauw, J. B. D., Gericke, N., Olsson, D., \& Berglund, T. (2015). The effectiveness of education for sustainable development. Sustainability, 7(11), 15693-15717.

Sammalisto, K., Sundström, A., von Haartman, R., Holm, T., \& Yao, Z. (2016). Learning about Sustainability_What Influences Students' Self-Perceived Sustainability Actions after Undergraduate Education?. Sustainability, 8(6), 510.

Sivamoorthy, M., Nalini, R., \& Kumar, C. S. (2013). Environmental Awareness and Practices among College Students. International Journal of Humanities and Social Science Invention, 2(8), 11-15.

Walker, J. P., Sampson, V., Southerland, S., \& Enderle, P. J. (2016). Using the laboratory to engage all students in science practices. Chemistry Education Research and Practice, 17(4), 1098-1113.

Wardani, T. B., \& Winarno, N. (2017). Using Inquiry-based Laboratory Activities in Lights and Optics Topic to Improve Students' Understanding About Nature of Science (NOS). Journal of Science Learning, 1(1), 28-35. 